\title{
When salespeople develop negative headquarters stereotypes: performance effects and managerial remedies
}

\author{
Christian Homburg • Jan Wieseke • Bryan A. Lukas • \\ Sven Mikolon
}

Received: 8 March 2010 / Accepted: 21 October 2010 /Published online: 18 November 2010

(C) Academy of Marketing Science 2010

\begin{abstract}
This study examines the performance implications that organizations may suffer when their salespeople develop negative stereotypes of their corporate headquarters. How such stereotypes can be remedied through managerial action is also examined. The study draws on matched data from four different sources: sales managers, salespeople, customers, and company reports. Findings indicate that negative headquarters stereotypes among salespeople are associated with poor marketing-related performance across a range of outcomes, including salespeople's adherence to corporate strategy, their customer orientation, and their sales performance. Findings also show that negative headquarters stereotypes can be remedied through managerial action, but more so at the corporate management level than at the sales unit level.
\end{abstract}

Keywords Stereotypes - Salespeople · Sales management . Corporate headquarters $\cdot$ Customer orientation

All authors contributed equally to this article.

C. Homburg $(\bowtie)$

University of Mannheim,

Castle, 68131 Mannheim, Germany

e-mail: homburg@bwl.uni-mannheim.de

C. Homburg • B. A. Lukas

Department of Management and Marketing,

University of Melbourne,

Melbourne, Victoria 3010, Australia

B. A. Lukas

e-mail: blukas@unimelb.edu.au

J. Wieseke $\cdot$ S. Mikolon

Ruhr-University of Bochum,

44780 Bochum, Germany

J. Wieseke

e-mail: jan.wieseke@rub.de

S. Mikolon

e-mail: sven.mikolon@rub.de

\section{Introduction}

In our local sales organization, our salespeople believe that our headquarters personnel are too comfortable in their fancy offices and have no clue about what customers are saying. This has been worrying me for some time because it does not go unnoticed by our customers and also makes strategy implementation in the field fairly difficult.

\section{General Manager of a Large Pharmaceutical Company}

It is true that we sometimes have negative beliefs towards our headquarters among our sales representatives at the coalface. That we are seen to be more interested in our headquarters' perks than in our company's welfare is just one of those things we executives have to live with. Anyway, I do not perceive this to be a major problem. Such beliefs crop up in many organizations I know.

\section{Executive Director of an International Bank}

Stereotypes can be defined as over-generalized, illogical, or rigid beliefs about members of certain groups (Krueger et al. 2008; for a review see Hilton and von Hippel 1996). Stereotypes involve judgments of how typical certain personality traits are of a group (Krueger et al. 2008). The effects of stereotyping can vary, but they tend to be negative in most cases (e.g., Cuddy et al. 2007). For instance, a number of empirical studies in sociology and social psychology (e.g., Bargh et al. 1996; Caprariello et al. 2009; Chen and Bargh 1997; Devine 1989; Cuddy et al. 2007; Heilman and Okimoto 2008) conclude that stereotypes result in discrimination against targeted groups, e.g., in the form of scapegoating, judgmentalism, lack of support for the target group, and lack of performance on behalf of 
the target group. Perceived differences among social groups precondition stereotypes. Physical separation of social groups entrenches perceptions of group differences and, hence, further preconditions the development of stereotypes (e.g., Fiske 1998; Turner et al. 1987).

For salespeople, a potential stereotype target can be found in corporate headquarters. The first reason is that people working in corporate headquarters are often perceived to be distinctively different from people working in a sales force. Hence, from a salesperson's perspective, people in corporate headquarters lend themselves to particular social comparisons such as those mentioned in the quotations at the beginning of this paper. The second contributing factor is that a sales force is often separated from corporate headquarters to a greater degree than other business functions. The separation is normally due to the need for salespeople to be close to their customers. Firms operating with a dealer or branch structure are organizational examples of firms with a sales force markedly separated from their headquarters.

Whether the stereotyping of corporate headquarters by salespeople bears any implications for a firm is an open question. The sociology and social psychology literature, at least, point to some notable implications, as outlined in the introductory paragraph. Within the marketing discipline, stereotype-related phenomena have been addressed in fields such as consumer racism (e.g., Ouellet 2007), consumer ethnocentrism (e.g., Shimp and Sharma 1987), and consumer animosity (e.g., Klein et al. 1998). Beyond these consumer behavior studies, the concept of stereotyping has not been examined from a managerial perspective in the marketing literature and, hence, has not been applied to the circumstances defining the relationship of frontline, customer-facing employees with their corporate management.

This study introduces the concept of stereotyping to the literature on sales force management. In a first step, we analyze the managerial relevance of salespeople developing negative stereotypes of their corporate headquarters by linking these negative stereotypes to key marketing-related performance outcomes in organizations, such as salespeople's adherence to corporate strategy, their customer orientation, and their sales performance. In doing so, we attempt to answer the fundamental question underlying the quotations heading this paper: to what extent do negative headquarters stereotypes (NHS) in a firm's sales force constitute a problem for the firm? In a second step, we analyze how these stereotypes can be remedied. To this end, we address whether NHS can be managed more effectively at the corporate level or the sales unit level. More specifically, we examine whether management actions originating from within the stereotyping sales force or, instead, from the targeted corporate headquarters are more important NHS remedies.
To gain a broad and empirically robust understanding of the potential outcomes of NHS, we drew data from salespeople, customers, and sales performance records. To understand potential corporate management and sales unit management remedies for salespeople's NHS, we drew data from sales managers and salespeople. Overall, our analysis is based on matched responses from 1,009 salespeople, 472 sales managers, and 499 customers, and incorporates secondary firm data on salespeople's performance.

Given the absence of stereotype research in the sales management literature, one contribution of this study is to introduce marketing researchers who are interested in sales management to the importance of including stereotype phenomena in predictions and explanations of sales-related performance. For practitioners, it is important to understand how the development of salespeople's NHS can be avoided - and why it should be avoided-by managerial action at both the sales unit and corporate level, and how the effects of these actions differ between these two management levels.

In the next section, we provide an overview of the theories underlying the concept of stereotyping. Then we develop a conceptual framework consisting of specific hypotheses about some likely outcomes of, and remedies for, NHS held by salespeople. Subsequently, we discuss how we tested the hypotheses. After reporting the results, we discuss the theoretical and managerial implications of our findings.

\section{Theoretical background}

The basic meaning of the term stereotype originates from the Greek stereos (solid, firm) and typos (impression, imprint). Stereotypes have been described as overgeneralized, illogical, or rigid beliefs about members of certain groups (Krueger et al. 2008). These beliefs are endorsed and accepted as being true. Theoretical explanations for why stereotypes develop are provided by the cognitive approach and social identity approach in the extant literature.

The cognitive approach maintains that, to make sense of the world and reduce social complexity, people often categorize each other as members of a social category, and they often do this unconsciously (e.g., Bargh and Chartrand 1999; Bargh et al. 1996). The categorization process involves the exaggeration of between-category differences (e.g., Corneille and Judd 1999; Queller et al. 2006) and within-category similarities (e.g., Livingston et al. 1998). These exaggerations can lead to a distortion of what the characteristics of individual category members actually are because the over-generalized category stereotype is applied to all members of the category (e.g., Park et al. 1990). Most 
importantly, research conducted in the cognitive tradition of social psychology also shows that people can unconsciously engage in stereotyping (e.g., Bargh and Chartrand 1999; Bargh et al. 1996; Devine 1989). Overall, the cognitive approach discusses stereotypes as perceptual processes and explores stereotypes formation, how stereotypes are stored in memory, how they shape judgment, and behavior when stereotypes are activated (Akrami 2005).

The social identity approach (Hogg and Abrams 1988; Tajfel and Turner 1979; Turner et al. 1987) provides a motivational explanation for why stereotypes emerge and focuses on people's group memberships (Akrami 2005). The central assumption of the social identity approach is that a person's sense of identity is a function of belonging to a social group (referred to as the in-group) that is superior to other social groups (referred to as out-groups). For reasons of self-enhancement, if the in-group and out-groups turn out to offer similar identity benefits, then members of the in-group will seek to attribute negative associations - derived from perceived group differences - to the out-groups, or attribute positive associations to the in-group; that is, the members of the in-group develop stereotypes (e.g., Tajfel and Turner 1979; Turner et al. 1987).

For the theoretical underpinning of our study we rely on the social identity approach. This choice is based on two reasons. First, the social identity approach considers people's group memberships to be a major source of intergroup stereotyping (Akrami 2005), and the present study concentrates on organizational groups. Second, the explanatory power of the social identity approach for group behavior in organizations has been demonstrated by previous research (e.g., Ashforth and Mael 1989; Ellemers et al. 2004).

Within the social identity approach, the distinction between in- and out-groups plays a crucial role. In the context of the present study, members of corporate headquarters, including corporate-level managers, constitute an out-group; and members of the sales unit, including the sales unit managers, constitute the in-group. Considering corporate headquarters members as a separate social group is appropriate for two reasons: First, as mentioned before, they are usually physically separated from the sales force. Second, the kinds of activities carried out at headquarters are largely different from those in the sales force- the typical interaction of salespeople is with customers, whereas headquarters members typically have much less customer interaction.

\section{Hypotheses}

Our conceptual framework is depicted in Fig. 1. The central construct in this framework is salespeople's negative headquarters stereotypes. To the left of this construct, we present management factors that may affect NHS among salespeople, grouped into corporate and sales unit factors. The inclusion of both a corporate and sales unit perspective in this study allows us to more comprehensively analyze how negative stereotypes in organizations can be minimized by managerial action at different organizational levels. The right part of the conceptual framework addresses potentially important employee, customer, and financial consequences of NHS among salespeople. A number of control variables are included in our conceptual framework to optimize its specification.

A series of hypotheses underpin the conceptual framework. Our hypotheses regarding the consequences of salespeople's NHS are motivated by the following question: Is a firm's employee, customer, and financial performance associated with its salespeople harboring negative stereotypical views of their corporate headquarters? For example, to what extent will salespeople be inclined to adhere to corporate strategy, be customer oriented, and meet sales targets if they harbor the stereotypical beliefs referred to in the two quotations stated at the outset of this paper?

Our hypotheses regarding the managerial influences on salespeople's NHS are motivated by the following question: Which management factors are associated with less negative stereotypical views of corporate headquarters among salespeople - management factors originating from within the stereotyping in-group (here the sales force) or from the targeted out-group itself (here the corporate headquarters)? The five management factors we focus on in our conceptual framework - organizational support, employee orientation, charismatic leadership, corporate bureaucracy, and sales unit manager's own stereotypes - were chosen because they emerged from the extant literature that we reviewed for this study as potentially important factors for stereotype management. Building on the social identity approach, we now turn to our hypotheses.

Consequences of salespeople's negative headquarters stereotypes

Two of the main intrapsychological processes underlying the social identity approach provide a plausible explanation for both why salespeople can develop NHS, and why NHS can affect the performance of salespeople adversely. These processes are: social categorization and social comparisons (Ellemers et al. 2004; Tajfel and Turner 1979).

When people categorize themselves in terms of a group, this group becomes incorporated into people's self-concept, resulting in a social identity. Social identity can be defined as "that part of an individual's self-concept which derives from his knowledge of his membership of a social group (or groups) together with the value and emotional significance attached to that membership" (Tajfel 1978, p. 63). Once a social identity 


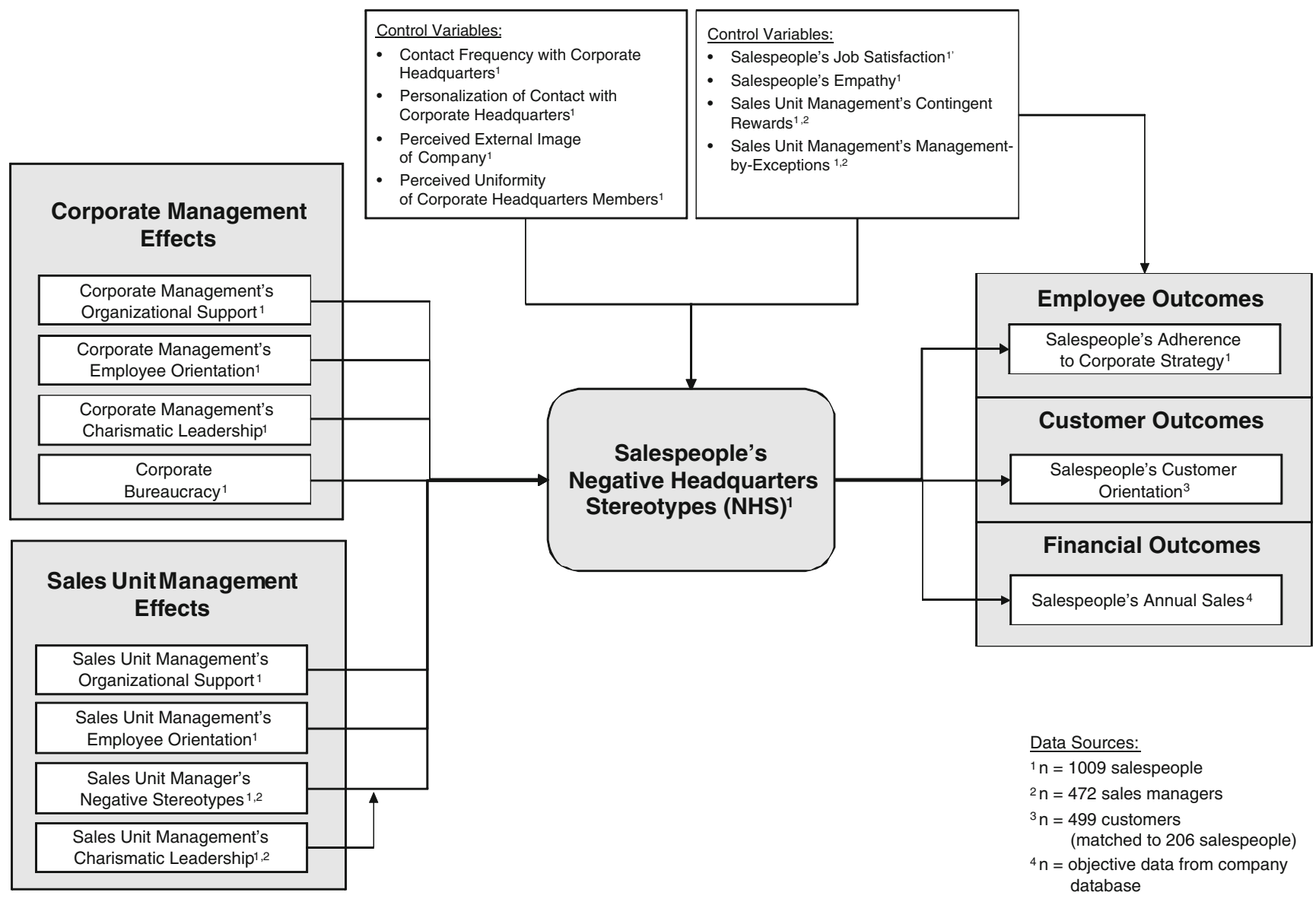

Fig. 1 Conceptual framework and data sources. Note: Some constructs were measured from more than one data source. When this is indicated in the figure, then results remain stable irrespective of the measurement level

is formed, group members tend to act on behalf of those groups comprising their identities (e.g., Ashforth and Mael 1989), i.e., they show behaviors supporting their groups.

Social comparison refers to the process by which a social categorization (here in terms of an organizational group) is invested with meaning (Ellemers et al. 2004). More specifically, for reasons of self-enhancement, group members try to favorably distinguish their own in-group from other relevant comparison-groups through social comparisons (e.g., blue-collar workers vs. white-collar workers). This comparison process, in turn, is biased in favor of the in-group in order to provide the in-group with a positive social identity and has been shown to account for stereotypes (e.g., Tajfel and Turner 1986). According to social identity theory, self-enhancement is the key motivational reason for intergroup stereotyping and discriminatory behavior against out-groups.

Furthermore, research in social psychology confirms that a high level of negative stereotypes of a group can lead to a higher level of negative judgments, behavioral intentions, and negative actual behavior against that group (e.g., Bargh et al. 1996; Chen and Bargh 1997; Devine 1989). Research further shows that stereotypes elicit emotions which shape behavioral tendencies (e.g., Cuddy et al. 2007).

Given the potential impact of stereotypes on individuals' behavior, we expect negative behavioral outcomes from stereotypes in a sales context. We explain next three likely such NHS-induced performance outcomes: salespeople's adherence to corporate strategy, their level of customer orientation as perceived by customers, and their annual sales levels.

Salespeople's adherence to corporate strategy The adherence of salespeople to corporate strategy can be defined as the tendency of salespeople to follow the procedures and guidelines established by corporate headquarters (Tyler and Blader 2005). Employees' strategy adherence is an important aspect of employee performance because it is fundamental for organizations to function effectively (O’Reilly 1989).

Salespeople have a high degree of freedom in their strategy adherence behavior. Consequently, previous research has found that command and control devices can explain only a small portion of strategy adherence behavior 
among sales employees (e.g., Tyler and Blader 2005). Given the impact of stereotypes on behavior, as suggested by social identity-related research, it is likely that salespeople holding strong negative stereotypes of corporate headquarters may subtly reject, or even blatantly boycott, sales strategy suggestions and directives that are handed down by corporate headquarters. This link between stereotypes and strategy adherence can be explained with social identity theory.

According to the social comparison assumption, NHS form to positively distinguish salespeople's identities from their corporate headquarters. As a result, NHS will consist of beliefs that members of corporate headquarters are an inferior out-group. Therefore, NHS are likely to make salespeople reluctant to comply with sales strategies (e.g., new salesforce automation systems) and selling-behavior strategies (e.g., prescribed customer-greeting behavior) decreed by corporate headquarters. Therefore, we hypothesize:

H1: The more negative salespeople's headquarters stereotypes are, the less the salespeople will adhere to corporate strategy.

Salespeople's customer orientation Salespeople's behavioral focus on creating customer value defines their level of customer orientation. Building on the social identity based service- profit chain (Homburg et al. 2009), which is an extension of the conventional service-profit chain described by Heskett at al. (1997), we suggest for a number of reasons that salespeople's NHS are likely to have a negative effect on salespeople's customer orientation.

Research on the service-profit chain (e.g., Heskett et al. 1997) shows that customer value is created by satisfied and loyal employees who identify with their organization. According to Heskett et al. (1997), loyal employees are those who are content with, and enthusiastic about, their organization and, therefore, are in a position to genuinely excite customers. Satisfied employees have a passion for their organization and believe that they are making a contribution to something meaningful. Hence, they have a strong ability to provide memorable experiences for customers. Employees who identify themselves with their organization become prototypical representatives of their organization, i.e., they are more inclined to conform to organizational norms and peculiarities (Homburg et al. 2009). As a result, they are able and inclined to fully utilize the organization's resources and, therefore, can comprehensively respond to customer wishes and solve customer problems.

Applied to the research context of this study, the social identity based service-profit chain predicts that salespeople will be customer-oriented and, thus, create customer value if the salespeople are satisfied, loyal, and identify themselves with their organization. This prediction is consistent with a large stream of research. For instance, Hoffman and Ingram (1992) and Homburg and Stock (2004) show a positive link between employees' work satisfaction and their customer-oriented behavior. Furthermore, Homburg et al. (2009) find a positive relationship between employee's company identification and employee's customer orientation. Puffer (1987) and Smith et al. (1983) show work satisfaction to be related positively to pro-social behaviors, including helping behaviors, in organizations.

However, according to the social comparison principle of social identity theory, salespeople who harbor NHS are not likely to be productive, loyal, and satisfied. Rather, as noted earlier, for reasons of self-enhancement, negative stereotypes tend to result in negative behavioral intentions and actual behavior associated with the stereotype target (here the corporate headquarters of the organization) (e.g., Bargh et al. 1996; Chen and Bargh 1997; Cuddy et al. 2007). Hence, it is unlikely that salespeople with NHS will be perceived to be very customer-oriented. Therefore, we put forward the following hypothesis:

H2: The more negative salespeople's headquarters stereotypes are, the less the salespeople will be perceived to be customer-oriented by customers.

Salespeople's annual sales Besides the impact on important employee and customer outcomes, salespeople's NHS may also be detrimental to financial outcomes such as the sales revenue that stereotyping salespeople are able to achieve. There are several reasons for this possibility.

Social identity research shows that in-group members often communicate, and as a result can transmit, their stereotypes to non-group members who are not part of the stereotyped out-group. For example, Stephan and Stephan (1984) show that educators often pass their stereotypes on to their pupils. Because salespeople and customers directly interact with each other, it is possible that salespeople with NHS may transmit these stereotypes to their customers, for example, during a sales conversation, where the customer consults a salesperson for advice and an opinion. Because customers often put a greater weighting on negative information than on positive information in the formation of evaluative judgments (Ahluwalia 2002) and in the making of decisions (Herr et al. 1991), it is possible that the transmission of NHS by a salesperson may have a negative effect on a customer's more general perception of the salesperson's organization and, thus, on how desirable it is to purchase from an organization portrayed so negatively by an employee.

In addition, harboring NHS can absorb cognitive capacity (e.g., Kearney et al. 2009; Zyphur et al. 2007). 
When cognitive capacities are taxed, fewer capacities remain for the core job tasks (e.g., Engle and Lord 1997), especially in the case of cognitively demanding tasks such as selling. Further, the sharing and reinforcing of NHS that is common among in-group members harboring stereotypes, such as discussing recent "mishaps" by corporate headquarters among stereotyping salespeople, might distract from selling. Therefore, we hypothesize:

H3: The more negative salespeople's stereotypes are, the less sales the salespeople will generate.

Managerial influences on salespeople's negative headquarters stereotypes

We first concentrate on managerial factors that can be deployed at both the corporate headquarters level and sales unit level: organizational support, employee orientation, and charismatic leadership. Then we turn to managerial factors that are specific in their deployment to either corporate headquarters or the sales unit: corporate bureaucracy and sales unit manager's own stereotypes, respectively.

Organizational support As perceived by employees, organizational support can be defined as employees' "global beliefs about the extent to which the organization cares about their well-being and values their contributions" (Eisenberger et al. 1986, p. 501). Piercy et al. (2006) specify this definition for the sales context: "Salesperson perceptions of organizational support capture several aspects of work experiences by considering how the salesperson feels about the organization's commitment and assistance to the individual in performing his or her job responsibilities" (p. 250).

Previous research has found perceived organizational support to be an important antecedent of beneficial employee outcomes. For instance, Tyler (1999, p. 235) concludes that employees "remain loyal when they feel that their organizations [...] value and appreciate them". Rhoades and Eisenberger (2002) identify positive links between perceived organizational support and what Gouldner (1960) calls the "norm of reciprocity". This norm describes the tendency of "recipients of favourable treatment to help and to avoid harming those who have aided them" (Eder and Eisenberger 2008, p. 56). This reciprocal trade between employees and their organization also strengthens employee-organization relationships. When applied to our research context, these findings point to the possibility that salespeople with high perceived organizational support from corporate management are likely to avoid expressing harmful stereotypes of their headquarters (see Eder and Eisenberger 2008). Indeed, employees may even feel obligated to increase their positive outputs (e.g., positive attitudes and behaviors), while reducing negative outputs (e.g., stereotypes and harmful behavior), in exchange for feeling supported by corporate management.

In addition, perceived organizational support can help to blur the salience of group identities because it may trigger decategorization processes. As a consequence out-groups may be judged more favorably and accurately (see Anastasio et al. 1997).

Turning to the sales unit management level, we reason that the effect of sales unit managers' organizational support on salespeople's NHS is essentially one that bridges perceived boundaries or differences between salespeople in the sales unit and people in corporate headquarters. Specifically, following the logic of the social identity approach, negative "us vs. them" feelings held by salespeople may be weakened if sales employees perceive their sales unit to be supporting them in achieving corporate objectives on the one hand and, on the other hand, also to be their advocate at headquarters. Thus, the perception that the sales unit actively supports salespeople in their job execution and supports their interests at the corporate level should reduce any perceived separation from headquarters and, thus, reduce the propensity for NHS among salespeople. In addition, the more that sales employees perceive their sales unit to care for them, the more the sales employees are likely to feel central to the corporation, which may further reduce "us vs. them" notions. Salespeople then self-categorize more strongly in terms of the whole organization so that one holistic in-group arises. Therefore, we hypothesize:

H4: The likelihood that salespeople stereotype their headquarters negatively decreases the more the salespeople are supported by their (a) corporate management and (b) sales unit management.

Employee orientation In both the marketing and management literature, employee orientation is considered to be an important dimension of managerial behavior (e.g., Baker and Sinkula 1999; Fritz 1996; Liu et al. 2002). Employee orientation relates to "firms' internal focus on human resources, putting employees' well-being and satisfaction before other stakeholders" (Grinstein 2008, p. 119). As a second important management factor to combat stereotypes, we posit employee orientation to be inversely related to NHS that salespeople may harbor.

Although employee orientation is related to organizational support, it is unique in its focus on de-centralized decisionmaking processes, investments in employees' development, and delegation of responsibility (Fritz 1996; Harris and 
Ogbonna 2001; Piercy et al. 2002). These components are thought to increase organizational members' satisfaction, motivation, and organizational commitment (Fritz 1996; Ruekert 1992). Previous empirical research (e.g., Fritz 1996; Harris and Ogbonna 2001; Pfeffer and Veiga 1999) largely supports these notions.

Again our reasoning can be based on the categorization assumption of the social identity approach. More specifically, we argue that a high level of employee orientation should strengthen employees' beliefs that members of their corporate headquarters adhere to the same goals as they do. This, in turn, should lead salespeople to self-categorize more strongly in terms of their organization (not just in terms of salespeople) and, therefore, prevent negative stereotypes of their corporate headquarters.

At the sales unit level, too, a high level of employee orientation displayed by sales unit management can help to bridge the perceived gap between salespeople and corporate headquarters, thus reducing the propensity for NHS among salespeople. Hence, similar to the corporate management level, we suggest that sales unit management's employee orientation can lead to a decrease in headquarters stereotypes. In summary, we propose:

H5: The likelihood that salespeople stereotype their headquarters negatively decreases the more employee orientation the salespeople experience from their (a) corporate management and (b) sales unit management.

Charismatic leadership It is widely accepted in behavioral models of leadership that charismatic leaders are individuals who possess high sensitivity to the environment and followers' needs, articulate an attractive vision for the organization, and inspire subordinates to follow their attitudes and behaviors (Conger and Kanungo 1998; Conger et al. 2000). Empirically, previous research on charismatic leadership (e.g., Conger et al. 2000; Shamir et al. 1993) has found that charismatic leaders have a profound influence on followers' attitudes and behavior, ranging from heightened motivation, trust in the leader, low role conflict and ambiguity to performance improvement, and vision for the organization. Followers are more likely to be attracted to, comply with, and internalize charismatic leaders' mission and directives because they regard these charismatic leaders as possessing inspirational qualities (Conger and Kanungo 1998; see also Kelman 1958).

With respect to potential "us vs. them" feelings of employees towards their corporate headquarters, such feelings are more likely to be dispersed by highly charismatic leaders due to their ability to influence followers' beliefs, attitudes, and behavior. In other words, highly charismatic leaders are likely to promote a collective organizational sense of belonging while boundaries between the internal groups become less salient. We are not aware of theoretical or empirical evidence to suggest that these charisma effects differ markedly if facilitated by leaders at the corporate or sales unit management level. Hence we propose the following relationship:

H6: The likelihood that salespeople stereotype their headquarters negatively decreases the more the salespeople are led charismatically by their (a) corporate management and (b) sales unit management.

We now turn to the headquarters stereotype remedies that are specific to either corporate management or sales unit management: corporate bureaucracy and sales unit manager's potential stereotypes, respectively.

Corporate bureaucracy Although some corporate bureaucracy may be necessary for steering organizations (e.g., Dugger 1980), both management and marketing researchers have highlighted the potential harm of corporate bureaucracy. For instance, Leonard (2000) notes that employees rank less organizational bureaucracy as the biggest boost to productivity, and too much organizational bureaucracy as their primary complaint. Piercy (1994) states that bureaucracy "usually does not deal with the issues that matter, and may actually make things worse."

Corporate bureaucracy imposed on employees symbolizes a large distance between corporate leadership and employee groups. According to the social identity approach, such perceived distance raises the likelihood of intergroup stereotypes because it is easier for salespeople to self-categorize in terms of their own group than it is for them to try and include other groups which are seen as being distant. In turn, social comparison processes are more likely and, hence, so is intergroup stereotyping (e.g., Bettencourt et al. 1992; Brewer and Miller 1984; Miller et al. 1985). Therefore, we propose:

H7: The likelihood that salespeople stereotype their headquarters negatively decreases the less bureaucratic the salespeople's corporate management is.

Sales unit management's stereotypes The explanation for the positive influence of sales unit managers' stereotypes on salespeople's stereotypes can be adopted from existing research on "trickle-down" effects, which have been found for important marketing constructs. For example, trickle down of manager attitudes has been found for market 
orientation (Jones et al. 2003) and brand adoption (Wieseke et al. 2008).

Theoretically, trickle-down effects have been explained with social learning theory and planned behavior theory. Both theories can be linked to the social identity approach (e.g., Terry and Hogg 1996). Social learning theory suggests that individuals learn by observing significant others (Luthans and Kreitner 1985). Planned behavior theory (Ajzen and Madden 1986) is centered on the concept of "subjective norm", which is also important for the trickle down of attitudes. A subjective norm represents an individual's perception of whether significant others will welcome or reject a given attitude or behavior (Ajzen 1985). These subjective norms have been found to directly relate to individual attitudes and behavioral intentions (e.g., Ajzen and Madden 1986).

From a social identity theoretical perspective, people construct a social norm from shared social comparative information (Terry and Hogg 1996). According to the social comparison process, which is fundamental to social identity theory, stereotypes serve to favorably distinguish the ingroup from other relevant comparison groups. Therefore, stereotypes can be conceived to contain (biased) social comparative information. It follows that out-group stereotypes can act as social norms for in-group members (see also Oakes et al. 1994). For in-group members, in turn, their leaders can act as significant others (e.g., Ullrich et al. 2009). Thus, we predict that salespeople utilize their evaluations of sales managers' stereotypes of corporate headquarters as a subjective norm in forming their own headquarters views. This trickle-down effect leads to the following hypothesis:

H8a: The likelihood that salespeople stereotype their headquarters negatively increases the more their sales unit managers harbor negative stereotypical views of corporate headquarters.

The relationship proposed in H8a, however, is likely to be contingent on sales unit managers' charismatic leadership ability highlighted in H6. Specifically, the trickle-down effect of sales unit managers' headquarters stereotypes on similar stereotypes held by their salespeople should be significantly stronger if the sales unit managers are very charismatic.

An explanation for this moderator effect is provided by social identity theory. As noted already, charismatic leaders are those who articulate an attractive vision for the organization and inspire subordinates to follow their attitudes and behaviors (Conger and Kanungo 1998; Conger et al. 2000). This might cause followers to perceive a leader as "one of them" who stands for what group members have in common and what distinguishes them from other groups (Ullrich et al. 2009; van Knippenberg and Hogg 2003). As a result, a charismatic leader can become a prototpypical part of the group they lead. Previous social identity-related research has shown that leader prototypicality is significantly related to ratings of leader endorsement (e.g., Platow and van Knippenberg 2001; Ullrich et al. 2009) This suggests that followers are more likely to adopt their leader's stereotypes if the leader displays high levels of charismatic leadership. More formally:

H8b: The positive relationship between the negative headquarters stereotypes of sales unit managers and their salespeople strengthens the more the salespeople are led charismatically by their sales unit managers.

\section{Control variables}

We controlled for several factors that potentially influence salespeople's corporate headquarters stereotypes and the performance variables (adherence to corporate strategy, customer orientation and sales performance). Our factor selection is based on existing research related to stereotypes in social psychology and previous research in marketing.

Regarding both the overall performance variables (salespeople's sales performance, their customer orientation and their adherence to corporate strategy) and NHS, we controlled for salespeople's job satisfaction because it has been shown to be influential in previous research (e.g, MacKenzie et al. 1998a, b). Furthermore, because salespeople's traits have also been shown to be of importance for their performance (e.g., Brown et al. 2002), we controlled for salespeople's empathy (e.g., Bush et al. 2001). Finally, we controlled for contingent reward and management-byexceptions leader behaviors as typical manifestations of an transactional leadership style (which can be salesperformance enhancing) (e.g., Morhart et al. 2009).

In addition to the aforementioned variables, we controlled for effects of intergroup contact, perceived external image of the company, and perceived uniformity of the headquarters members on NHS. These controls are motivated by the following reasons.

A classical variable in stereotype research is intergroup contact. Since the seminal work of Allport (1954), more than 500 studies have dealt with this variable. While there is debate about the effects of intergroup contact on stereotypes (e.g., Hopkins et al. 1997), Pettigrew and Tropp (2006) find in their meta-analysis that intergroup contact typically reduces the development of negative stereotypes. In accordance with previous research, we included both contact frequency (e.g., Van de Ven and Ferry 1980; Vonofakou et al. 2007) and personalization of contact 
(e.g., Turner et al. 2007) between salespeople and corporate headquarters as control variables.

We also controlled for perceived external image of a company-sometimes referred to as "construed external image" or "organizational prestige" (e.g., Ahearne et al. 2005; Bergami and Bagozzi 2000; Smidts et al. 2001). This factor refers to a person's beliefs about outsiders' perceptions of the company. It is conceivable that when employees perceive the external image of a company as attractive (i.e., employees believe that the attributes that distinguish the company are positive and socially valued by relevant others), employee identification with the company is strengthened. This, in turn, may induce employees to recategorize their perceptions of group boundaries and, therefore, stop them from developing negative stereotypes of aspects or members of their organization.

We also controlled for any perceived uniformity of corporate headquarters members - also refered to as "entitativity". Entitativity is the degree to which members of a group are perceived as being a coherent social unit (Spencer-Rodgers et al. 2007). Social psychology theorists have argued that this variable leads to a process of depersonalization of out-group members; a process involving stereotypes which is considered to be a determinant of prejudice formation (e.g., Devine 1995). Previous empirical prejudice research has shown that the perception of high uniformity involves the abstraction of a stereotype of an out-group and the transfer of that stereotype across all out-group members (e.g., Crawford et al. 2002).

In order to test the robustness of our conceptual framework, we conducted our analyses with and without inclusion of the control variables. The results of these analyses showed that the findings that we present below are stable irrespective of the inclusion of these variables.

\section{Methodology}

\section{Collection of multilevel data from four sources}

We tested our conceptual model with data from travel agencies in a decentralized corporate structure. This research context is suitable for our study because it is characterized by a distinct operative sales unit structure (the individual travel agencies) and an organizational separation between operative sales units and corporate centers (the headquarters of the travel agency corporations). As operative sales units, agencies embeded in a decentralized corporate structure are also characterized by close employee-customer interactions - a context characteristic that is especially conducive to testing potential customer reactions to employees' headquarters stereotypes.
A major challenge for us in this study was to obtain access to data on salespeople's and sales managers' stereotypes because of the highly sensitive nature of this phenomenon. Stereotype data in our context are sensitive because, from the respondents' perspective, answering questions about stereotypes may reveal company views that could be subject to fines and even legal punishment in some cases (see Akrami 2005). Against this background, a prerequisite for obtaining access to stereotype data was for us to gain the trust of our potential respondents. Corporate management, the salespeople, and the sales managers who we surveyed all indicated that they placed a high level of trust in our university research team. An important contributor to the trust that we received was that we already had conducted a research project in the same firms on different constructs one year before the stereotype study took place.

While selecting the travel agencies for our study, we took a number of steps to make the sample as balanced as possible. A key issue was the inclusion of travel agencies from many different geographic locations in order to control for possible headquarters-proximity effects that could bias our results. ${ }^{1}$

Data for the study were collected in two stages. First, a qualitative study with in-depth, random interviews was conducted with salespeople from the travel agencies contained in our sample and managers from their corporate headquarters. The aim of interviewing the salespeople was to identify some of the typical negative beliefs that they harbored with regards to their headquarters. The managers were interviewed to then establish whether these beliefs reflected actual circumstances in the corporate headquarters or were exaggerated or over-generalized and, hence, stereotypical. Overall, this first stage helped deepen our understanding of how negative stereotypes manifest themselves in an organization and informed our measure of stereotypes.

In the next data collection stage, quantitative data were collected. An important feature of our quantitative study is that it is based on data from four different data sources (salespeople, customers, sales managers, and a company databank) and three respondent levels (salespeople, customers, and sales managers). Data on sales unit managers' stereotypes were collected from sales managers. Data on salespeople's stereotypes and strategy adherence

\footnotetext{
${ }^{1}$ Seven types of store locations emerged in the sample of travel agencies: large-sized city, first-class; large-sized city, central; largesized city, suburb; medium-sized city; small-sized city; airport; and shopping mall. However, including store location (operationalized as dummy variables) as a covariate did not exert any significant impact on the relationships we examined and, thus, this variable was dropped from further analyses.
} 
were collected from salespeople, as were all other predictor and control variable data. Data on perceived customer orientation were gathered from customers. Data on employee sales performance came from company databanks.

Data from the salespeople, customers, and sales managers were matched with the help of code numbers. With respect to the employee-customer dyads, interviewers allocated the customers to the respective employee's code number. The final matched sample consisted of 1,009 salespeople (response rate: $30.1 \%$ ), 472 sales managers (response rate: $44.5 \%$ ) in 472 travel agencies (with one manager per travel agency), and 499 customers (collected by interviewers for 206 salespeople; response rate: 41.4\%). The data sources for each measured construct can be seen in Fig. 1.

\section{Measures}

Appendix A provides a complete list of scales that we used. The scales' sources are also included. To measure the key construct in our study, NHS, we conducted a two-step scale development approach, which is consistent with existing work in this area (e.g., Babin et al. 1995; Gardner 1994; Katz and Hass 1988; Lee et al. 2007; Lepore and Brown 1997; McConahay et al. 1981; Turner et al. 2007; Vorauer et al. 1998; Wittenbrink et al. 1997).

We first conducted in-depth interviews with 15 travel agents using a projective word association technique to generate a list of characteristics that are most associated with corporate headquarters in the travel industry (most associated characteristics, or MACs). Then a sample of 25 travel agents was asked to complete a questionnaire containing all of the MACs identified in the in-depth interviews. The MACs were operationalized in the form of a statement describing the corporate headquarters. In order to identify which MACs were corporate headquarters stereotypes, we applied a stereotype differential technique (e.g., Gardner 1994; Lee et al. 2007). According to this technique, a significant polarity on the scale used to operationalize the MACs would reflect a stereotype. We conducted a one-sample $t$-test to determine those MACs that represented a corporate headquarters stereotype (e.g., Gardner 1994; Lee et al. 2007). The items in our NHS scale are the MACs that we found to represent corporate headquarters stereotypes.

We first conducted exploratory factor analyses to evaluate the factor structure for all the scales with more than one item, using promax rotation. Due to the multilevel structure of our data, we ran separate factor analyses for each data level. All items with cross loadings higher than .30 were excluded from further analyses. To further assess measure reliability and validity of our constructs, confirmatory factor analyses were conducted for each data level. Overall, the results indicated acceptable fit statistics (salespeople-level constructs: IFI $=.916$; $\mathrm{TLI}=.908 ; \mathrm{CFI}=.916$; sales-manager-level constructs: $\mathrm{IFI}=.922 ; \mathrm{TLI}=.907 ; \mathrm{CFI}=.922$; sales-manager-level constructs: $\mathrm{IFI}=.922 ; \mathrm{TLI}=.907 ; \mathrm{CFI}=.922$ ).

Table 1 displays the psychometric properties of our final scales, and Table 2 provides the correlations of the scales. Cronbach's alpha, composite reliability, and average variance extracted for all scales indicated sufficient reliability and convergent validity of our construct operationalizations. No coefficient alpha values and composite reliabilities were lower than .65 , thus meeting or exceeding the recommended thresholds by Bagozzi and Yi (1988) and Nunnally and Bernstein (1994).

We assessed the discriminant validity of the scales using the criterion proposed by Fornell and Larcker (1981), which is that discriminant validity is supported if the average variance extracted exceeds the squared correlations between all pairs of constructs. All constructs met this requirement.

To control for multicollinearity, we inspected the variance inflation factors of the variables. The control variables and the antecedents yielded values between 1.0 and 2.9, indicating the absence of serious multicollinearity problems (see Kleinbaum et al. 1998).

On the salespeople and sales manager level, nonresponse bias was assessed using Armstrong and Overton's (1977) time-trend extrapolation. No differences between early and late responders were detected on any of the constructs of interest or demographic variables within the two samples. In order to test for non-response bias in the customer sample, we chose the following approach. All visiting customers during the days of the interviews were offered the chance to participate in a lottery which was independent from the participation in the interviews. To take part in the lottery, customers had to provide their address and telephone number. We then collected additional data from 75 non-respondents by contacting them by telephone. Regarding the scale mean of the customer construct included in our framework, we did not find any significant differences between the respondents in our original sample and the non-respondent sample. These results provide evidence that non-response bias is not an issue in our data.

\section{Analytical approach}

As already noted, the data structure underpinning our study consisted of three levels: Customers, salespeople, and sales unit managers. In order to properly take this data structure into account (see Raudenbush and Bryk 2002), we 
Table 1 Psychometric properties of scales

\begin{tabular}{|c|c|c|c|c|c|}
\hline Variables & Mean & SD & $\alpha$ & $\mathrm{CR}$ & AVE \\
\hline 1. Salespeople's NHS & 3.83 & .79 & .78 & .78 & .38 \\
\hline 2. Salespeople's Adherence to Corporate Strategy & 5.69 & .83 & .72 & .73 & .41 \\
\hline 3. Salespeople's Customer Orientation & 6.50 & .60 & .92 & .92 & .70 \\
\hline 4. Salespeople's Annual Sales ${ }^{\mathrm{a}}$ & 570,027 & 180,601 & $-{ }^{\mathrm{b}}$ & $-{ }^{\mathrm{b}}$ & $-{ }^{\mathrm{b}}$ \\
\hline 5. Corporate Management's Organizational Support & 4.38 & 1.21 & .88 & .88 & .65 \\
\hline 6. Corporate Management's Employee Orientation & 4.06 & 1.06 & .84 & .85 & .59 \\
\hline 7. Corporate Management's Charismatic Leadership & 4.61 & .99 & .90 & .91 & .58 \\
\hline 8. Corporate Bureaucracy & 3.97 & 1.25 & .85 & .86 & .61 \\
\hline 9. Sales Unit Management's Organizational Support & 5.64 & 1.14 & .91 & .91 & .71 \\
\hline 10. Sales Unit Management's Employee Orientation & 4.99 & 1.40 & .93 & .93 & .76 \\
\hline 11. Sales Unit Manager's Negative Stereotypes & 4.09 & .83 & .75 & .77 & .37 \\
\hline 12. Sales Unit Management's Charismatic Leadership & 5.04 & 1.41 & .95 & .95 & .74 \\
\hline 13. Contact Frequency with Corporate Headquarters & 3.05 & 1.72 & $-{ }^{\mathrm{b}}$ & $-{ }^{\mathrm{b}}$ & $-{ }^{\mathrm{b}}$ \\
\hline 14. Personalization of Contact with Corporate Headquarters & 1.90 & 1.47 & .71 & .73 & .48 \\
\hline 15. Perceived External Image of Company & 5.26 & 1.18 & .93 & .93 & .78 \\
\hline 16. Perceived Uniformity of Corporate Headquarters Members & 3.83 & 1.01 & .86 & .87 & .63 \\
\hline 17. Salespeople's Job Satisfaction & 5.81 & 1.13 & .80 & .83 & .63 \\
\hline 18. Salespeople's Empathy & 5.13 & .92 & .84 & .85 & .65 \\
\hline 19. Sales Unit Management's Contingent Rewards & 5.93 & .82 & .85 & .87 & .57 \\
\hline 20. Sales Unit Management's Management by Exceptions & 5.39 & 1.05 & .80 & .82 & .53 \\
\hline
\end{tabular}

$C R$ composite reliability, $A V E$ average variance extracted

${ }^{a}$ Sales performance was measured with annual sales per employee (in thousands)

${ }^{\mathrm{b}}$ Construct measured through one item. Coefficient alpha, composite reliability, and average variance extracted cannot be computed

employed Mplus software (Version 6; Muthén and Muthén 2006) as this program permits the analysis of multilevel datasets.

\section{Results}

The results of our hypothesis tests are presented in Table 3. Our first three hypotheses focus on the outcomes of salespeople's negative stereotypes towards corporate headquarters and predict a negative effect of such stereotypes on salespeople's adherence to corporate strategy (H1), customer orientation (H2), and annual sales (H3). Results indicate that salespeople's negative stereotypes of corporate headquarters are related significantly and negatively to salespeople's adherence to corporate strategy $(b=-.372$, $\mathrm{SE}=.034, p<.01)$, customer orientation $(b=-.128, \mathrm{SE}=.039$, $p<.01)$, and annual sales $(\mathrm{b}=-26,062, \mathrm{SE}=11,814, p<.05)$. Hence, the data support $\mathrm{H} 1, \mathrm{H} 2$, and $\mathrm{H} 3$.

The next three hypotheses focus on how salespeople's stereotypes of their corporate headquarters are related to the same managerial action executed at both the corporate and sales unit level. Specifically, NHS are predicted to be related inversely to organizational support ( $\mathrm{H} 4 \mathrm{a}$ and $\mathrm{H} 4 \mathrm{~b})$, employee orientation (H5a and H5b), and charismatic leadership (H6a and H6b). Results show that salespeople's negative stereotypes of corporate headquarters are related significantly and inversely to corporate management's organizational support $(\mathrm{b}=-.151, \mathrm{SE}=.029, p<.01)$, employee orientation $(\mathrm{b}=-.114, \mathrm{SE}=.029, p<.01)$, and charismatic leadership $(\mathrm{b}=-.132, \mathrm{SE}=.033, p<.01)$. The coefficients for sales unit management's organizational support, employee orientation, and charismatic leadership, however, are insignificant. Hence, H4a, H5a, and H6a are supported, but H4b, $\mathrm{H} 5 \mathrm{~b}$, and $\mathrm{H} 6 \mathrm{~b}$ are not supported.

Our last two hypotheses concentrate on factors particular to either the corporate management level or sales unit management level. Specifically, salespeople's NHS are predicted to be related positively to corporate bureaucracy (H7). These negative stereotypes are also predicted to be related positively to sales unit managers' negative stereotypes of their corporate headquarters (H8a), with the relationship between sales unit managers' stereotypes and salespeople's stereotypes expected to be moderated positively by sales unit managements' charismatic leadership (H8b). Our results show that salespeople's NHS are related significantly and positively to corporate bureaucracy $(\mathrm{b}=.175, \mathrm{SE}=.022, p<.01)$. Our results also confirm that 


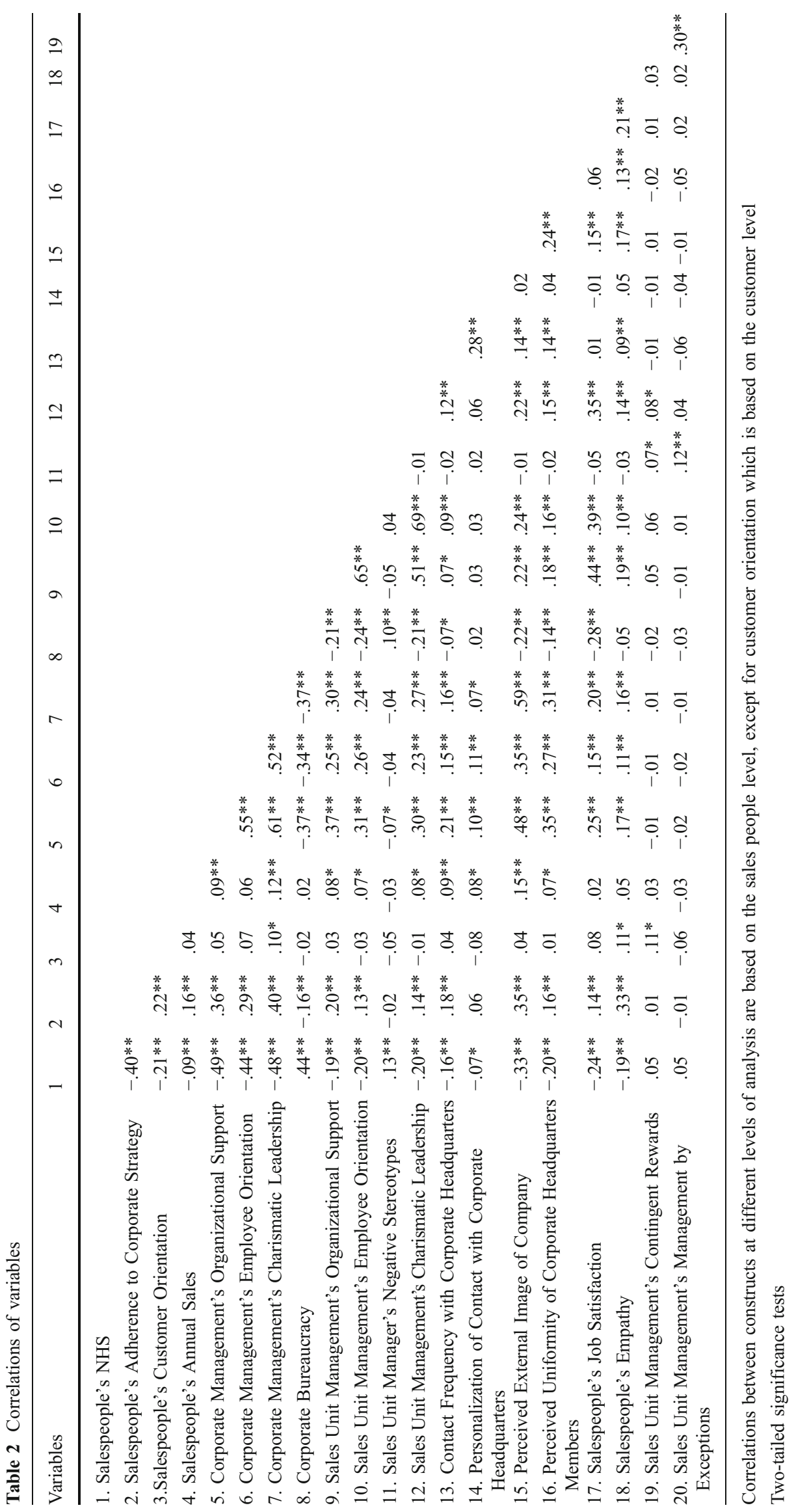




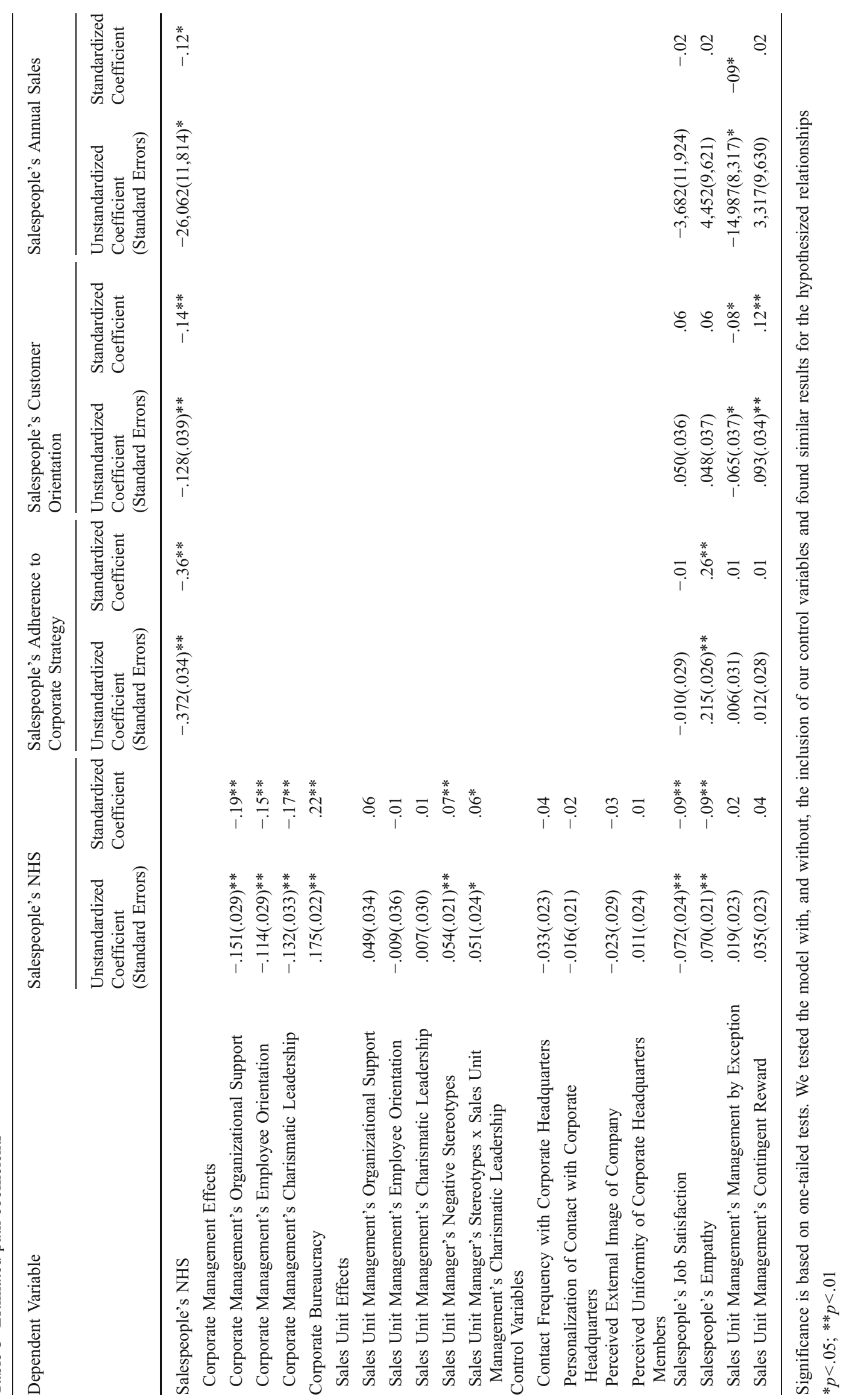


salespeople's NHS are related significantly and positively to sales unit managers' negative stereotypes of corporate headquarters $(\mathrm{b}=-.054, \mathrm{SE}=.021, p<.01)$, and that this relationship is moderated significantly and positively by sales unit managements' charismatic leadership $(b=.051$, $\mathrm{SE}=.024, p<.05$; high charisma: $\mathrm{b}=.116, \mathrm{SE}=.068, p<.05$; low charisma: $\mathrm{b}=.006, \mathrm{SE}=.070$, n.s.). Hence, the data support $\mathrm{H} 7, \mathrm{H} 8 \mathrm{a}$, and $\mathrm{H} 8 \mathrm{~b}$.

\section{Discussion}

Our research objectives were to introduce the concept of stereotypes to sales management research in marketing, analyze the relevance of the concept for sales force management, and determine its susceptibility to managerial influence. To the best of our knowledge, this is the first study (1) to conceptualize headquarters stereotypes from a marketing management perspective; (2) empirically examine potential employee, customer, and financial consequences of headquarters stereotypes among salespeople; and (3) empirically examine how such stereotypes can be reduced by managerial action at the corporate and sales unit level in a marketing context.

\section{Theoretical implications}

Our results show that NHS held by salespeople can have severe negative consequences for firm performance across three key outcomes considered relevant for salespeople. Specifically, we find that salespeople who have developed NHS of their corporate headquarters (1) are reluctant to adhere to a firm's sales strategy, (2) are perceived by customers to be less customer-oriented, and (3) display poorer sales performance.

These findings provide evidence that the concept of stereotypes, typically grounded in personality, social, and cognitive psychology, is highly relevant for the field of marketing. This high relevance is underlined by the fact that the data for the three dependent variables used in this study come from three different sources: salespeople's self assessments, customer perceptions, and objective data. The conceptual breadth of these three performance effects-ranging from strategy adherence to customer orientation to objective sales performance-further underlines the relevance of the stereotype construct for sales management.

Against this background, we suggest that sales management research should consider stereotyping in different contexts in the future. For example, it is possible that people in corporate headquarters hold negative stereotypes of salespeople. Additionally, research into the marketing interface with other functional units in an organization would benefit from considering stereotypes since it is entirely possible that members of one functional unit have negative stereotypes of members of another functional unit (e.g., marketing vs. sales; marketing vs. R\&D).

Regarding managerial remedies for negative stereotypes, we conclude that the corporate level is more important than the sales unit level. We base this conclusion on finding more support for our hypotheses at the corporate level than at the sales unit level. Further, we found a distinct difference in the importance of the same NHS remedies depending on the managerial levels of their execution. Specifically, while we found that corporate-level management support, employee-oriented behavior, and charismatic leadership explain salespeople's NHS, we did not find the same evidence at the sales unit level for the same factors. Overall, the possibility arises that management actions to combat negative stereotypes in a firm's context may be more effective when they originate from within the targeted out-group itself (here the corporate headquarters) rather than from within the stereotyping in-group (here the sales force).

Another noteworthy finding was that perceived bureaucracy is more strongly related to salespeople's stereotypes than any of the managerial antecedents considered in this study (see the standardized coefficients in Table 3). Apparently salespeople develop NHS to a significant extent when headquarters strongly formalize and standardize organizational processes. That such bureaucratic procedures can be interpreted more than any other factor included in this study as a headquarters-induced annoyance may partially explain our finding. Although the concept of bureaucracy, including its components, formalization and standardization, attracted a lot of research interest in the 1980s (e.g., Deshpande 1982), we note that in more recent research there has been less emphasis placed on this concept. Our analysis shows that bureaucracy should remain an important concept in marketing and sales studies.

Furthermore, future research should explore potential relationships between NHS and other important attitudinal responses of salespeople. For instance, researchers might wish to examine whether and how stereotypes are related to role ambiguity or role conflict (e.g., Hartline and Ferrell 1996).

\section{Managerial implications}

A key implication for management practice is that managers should take their salespeople's NHS very seriously. Our finding that NHS in the sales force are related to various performance outcomes, including subjective and objective 
salespeople performance, clearly tells managers that this phenomenon should not be neglected and should be monitored. The semantic differential scale that we developed on the basis of previous research in social psychology can serve as an easy-to-use monitoring tool.

Other important implications for managers relate to the remedies for salespeople's negative headquarters stereotypes. One implication is that managers can expect NHS remedies to be more effective if implemented at the corporate level rather than at the sales unit level. Our results also tell managers that they should not forget the negative performance consequences of organizational rules, regulations, and formalities. Specifically, we find that the strongest influence on stereotypes may emerge from corporate bureaucracy. We suggest, therefore, that managers should be careful about an escalation of bureaucracy in their organization. The benefits of bureaucracy are often fairly straight forward, but there are negative consequences such as an increased chance of NHS in sales units.

Our finding of a positive relationship between sales managers' stereotypes and salespeople's stereotypes - and the strengthening of the relationship subject to the degree of charismatic leadership displayed by the sales managersalso provides important managerial implications. One implication is that the superiors of sales managers should attempt to eliminate NHS held by sales managers because of the potential trickle-down effect of stereotypes from sales managers to salespeople. The second implication is that special consideration should be given to managers of sales units who have a highly charismatic leadership style. These individuals may be extremely helpful in the sales units if they do not harbor NHS, but extremely harmful if their NHS are entrenched.

\section{Conclusion}

This study was designed to open a new stream of research in the sales management literature around (1) the performance implications that organizations may suffer when their salespeople develop negative stereotypes of corporate headquarters and (2) the management of these stereotypes. Particular attention in this study was given to understanding how NHS can be minimized at different managerial levels of the firm. Our overarching finding is that NHS among salespeople are linked to key performance outcomes at the customer interface and can be reduced by managerial action at the corporate and sales unit level. We hope that our study findings will encourage academics and practitioners to consider any presence of headquarters stereotypes carefully in the future.

\section{Appendix}

\section{Scale Items for Construct Measurement}

I.\&II. Salespeople's [Sales Unit Manager's] Negative Headquarters Stereotypes (data source: sales managers and salespeople) Wittenbrink et al. (1997); Turner et al. (2007); Gardner (1994); seven-point sementic differential scale

1. The people in corporate headquarters know what is really involved with running a travel agency... (1) very well (7) not at all.

2. The people in corporate headquarters are primarily... (1) concerned with the interest of the travel agencies (7) concerned with their own interest.

3. The people in corporate headquarters earn... (1) too little (7) too much.

4. Compared to salespeople and sales managers, the people in corporate headquarters work... (1) more (7) less.

5. Compared to here, the working conditions in corporate headquarters are... (1) less pleasant (7) more pleasant.

6. Our corporate headquarters... (1) is worth more than it costs (7) costs more than it is worth.

III. Salespeople's Adherence to Corporate Strategy (data source: salespeople) Ajzen and Madden (1986); "totally disagree" to "totally agree" on a seven-point scale

1. I adhere to the strategic guidelines of our corporation.

2. I try my best to sell our corporate brands whenever it is possible.

3. To be able to optimally implement the strategic guidelines of my corporate headquarters, I make major efforts to stay well informed.

4. My main aim is to sell our corporate brands.

IV. Salespeople's Customer Orientation (data source: customers) Thomas et al. (2001); "totally disagree" to "totally agree" on a seven-point scale

1. The travel agent tried to figure out what my needs were.

2. The travel agent had my best interest in mind.

3. When selling me products, my needs were very important to the travel agent.

4. The travel agent recommended products or services that were best suited to solving my problems.

5. The travel agent tried to find out which kind of products or services would be most helpful to me.

V. Salespeople's Sales Performance (data source: firm records) Schneider et al. (2005)

1. Annual Sales per salesperson 
VI. \& VII. Corporate [Sales Unit] Management's Organizational Support (data source: salespeople) Eisenberger et al. (1986); "totally disagree" to "totally agree" on a seven-point scale

1. Help is available from corporate [sales unit] management when I have a problem.

2. Corporate [sales unit] management is willing to help me when I need a special favor.

3. Corporate [sales unit] management cares very much about my opinion as an employee.

4. Corporate [sales unit] management is proud of my achievements as an employee.

VIII. \& IX. Corporate [Sales Unit] Management's Employee Orientation (data source: salespeople) Fritz (1996); "totally disagree" to "totally agree" on a sevenpoint scale

1. The travel agents' interests are at the centre of corporate [sales unit] management's considerations.

2. Corporate [sales unit] management does everything for the well-being of the travel agents.

3. Much is done by corporate [sales unit] management for the personal and professional development of the travel agents.

4. Travel agent work satisfaction is a major goal of our corporate [sales unit] management.

X. \& XI. Corporate [Sales Unit] Management's Charismatic Leadership (data source: salespeople) Conger and Kanungo (1998); "totally disagree" to "totally agree" on a seven-point scale

1. Corporate [Sales unit] management has a vision that it tries to achieve with creative ideas.

2. Corporate [Sales unit] management provides inspiring strategic and organizational goals.

3. Corporate [Sales unit] management regularly creates new ideas to make the travel agencies [travel agency] ready for the future.

4. Corporate [Sales unit] management is comprised of entrepreneurial people who readily seize opportunities.

5. Corporate [Sales unit] management recognizes new opportunities in the market that help us achieve our organizational objectives.

6. Corporate [Sales unit] management is able to motivate the travel agents by articulating effectively the importance of what they are doing. [dropped from further analyses]

7. Corporate [Sales unit] management is comprised of individuals who represent the company convincingly to the external public.

8. Corporate [Sales unit] management is comprised of people one can be proud of.
XII. Corporate Bureaucracy (data source: salespeople)

"totally disagree" to "totally agree" on a seven-point scale

1. Working for [Company $\mathrm{X}$ ] is fairly difficult because of existing regulations.

2. Corporate management has imposed too many standards that impede my work.

3. In my daily work, I experience a high degree of bureaucratic impediments at the corporate level.

4. When I have a good idea, it is difficult to realize it because of bureaucratic corporate obstacles.

XIII. Contact Frequency with Corporate Headquarters (data source: salespeople) Van de Ven and Ferry (1980); "totally disagree" to "totally agree" on a seven-point scale

1. I stay in regular contact with corporate headquarters.

2. The Intranet is the only channel through which I have contact with corporate headquarters. (reverse coded) [dropped from further analyses]

XIV. Personalization of Contact with Corporate Headquarters (data source: salespeople) Turner et al. (2007); "totally disagree" to "totally agree" on a seven-point scale

1. I have friends in corporate headquarters. [dropped from further analyses]

2. I personally know some colleagues in corporate headquarters.

3. I have personally seen our corporate headquarters and I know it from within.

4. I know our corporate headquarters very well.

XV. Perceived External Image of Company (data source: salespeople); adapted from Ahearne et al. (2005); "totally disagree" to "totally agree" on a seven-point scale

1. Our corporation has a very good image in public.

2. The public appearance of our corporation is very good.

3. Other people like our corporate image in public.

4. Others like the advertising of our corporation.

XVI. Uniformity of Corporate Headquarters Members (data source: salespeople) Park and Judd (1990); "totally disagree" to "totally agree" on a seven-point scale

1. The members of corporate headquarters are very similar.

2. The members of corporate headquarters share many characteristics.

3. The members of corporate headquarters cope very well with each other.

4. Generally, the performance of our headquarters members is fairly similar.

XVII. Salespeople Job Satisfaction (data source: salespeople) Hackman and Oldham (1975); "totally disagree" to "totally agree" on a seven-point scale 
1. Generally speaking, I am very satisfied with this job.

2. I am generally satisfied with the kind of work I do in this job.

3. I frequently think of quitting this job (Reverse coded).

XVIII. Salespeople Empathy (data source: salespeople) Barrett-Lennard (1981); "totally disagree" to "totally agree" on a seven-point scale

1. I always sense exactly what customers want.

2. I realize what customer's mean even when they have difficulty in saying it.

3. It is easy for me to take the customer's perspective.

XIX. Sales Unit Management's Contingent Reward (data source: sales manager) Avolio et al. (1999); "totally disagree" to "totally agree" on a seven-point scale

1. I clarify rewards.

2. I assist my sales reps based on their effort.

3. I reward my sales reps' achievements.

4. I recognize my sales reps' achievements.

5. I continuously reward my sales reps' achievements.

XX. Sales Unit Management's Management-by-exceptions (data source: sales manager) Avolio et al. (1999); "totally disagree" to "totally agree" on a seven-point scale

1. I focus on my sales reps' mistakes.

2. I 'put out fires'.

3. I track my sales reps' mistakes.

4. I concentrate on my sales reps' failures

\section{References}

Ahearne, M. J., Bhattacharya, C. B., \& Gruen, T. (2005). Antecedents $\&$ consequences of customer-company identification: expanding the role of relationship marketing. Journal of Applied Psychology, 90(3), 574-85.

Ahluwalia, R. (2002). How prevalent is the negativity effect in consumer environments? Journal of Consumer Research, 29(2), $270-79$.

Ajzen, I. (1985). From intentions to actions: A theory of planned behavior. In J. Kuhl \& J. Beckmann (Eds.), Action control: From cognition to behavior (pp. 11-39). Berlin: Springer.

Ajzen, I., \& Madden, T. J. (1986). Prediction of goal directed behavior: attitudes, intentions, \& perceived behavioral control. Journal of Experimental Social Psychology, 22(5), 453-72.

Akrami, N. (2005). Prejudice: The interplay of personality, cognition, \& social psychology. Acta Universitatis Upsaliensis. Digital Comprehensive Summaries of Uppsala Dissertations from the Faculty of Social Sciences 5, Uppsala.

Allport, G. W. (1954). The nature of prejudice. Reading: AddisonWesley.

Anastasio, P. A., Bachman, B., Gaertner, S., \& Dovidio, J. F. (1997). Categorization, recategorization \& common ingroup identity. In R. Spears, P. J. Oakes, N. Ellemers, \& S. A. Haslam (Eds.), The social psychology of stereotyping \& group life (pp. 236-256). Oxford: Blackwell.
Armstrong, J. S., \& Overton, T. S. (1977). Estimating nonresponse bias in mail surveys. Journal of Marketing Research, 14(3), 396402.

Ashforth, B. F., \& Mael, F. (1989). Social identity theory and the organization. Academy of Management Review, 14(1), 20-39.

Avolio, B. J., Bass, B. M., \& Jung, D. I. (1999). Re-examining the components of transformational and transactional leadership using the multifactor leadership questionnaire. Journal of Occupational and Organizational Psychology, 72(4), 441-462.

Babin, B. J., Boles, J. B., \& Darden, W. R. (1995). Salesperson stereotypes, consumer emotions, and their impact on information processing. Journal of the Academy of Marketing Science, 23(2), 94-105.

Bagozzi, R. P., \& Yi, Y. (1988). On the evaluation of structural equation models. Journal of the Academy of Marketing Science, 16(1), 74-97.

Baker, W. E., \& Sinkula, J. M. (1999). The synergistic effect of market orientation and learning orientation on organizational performance. Journal of the Academy of Marketing Science, 27(4), 411-28.

Bargh, J. A., \& Chartrand, T. L. (1999). The unbearable automaticity of being. American Psychologist, 54(7), 462-479.

Bargh, J. A., Chen, M., \& Burrows, L. (1996). Automaticity of social behavior: direct effects of trait construct \& stereotype activation on action. Journal of Personality and Social Psychology, 71(2), 230-244.

Barrett-Lennard, G. T. (1981). The empathy cycle: refinement of a nuclear concept. Journal of Counseling Psychology, 28(2), 91-100.

Bergami, M., \& Bagozzi, R. P. (2000). Self-categorization, affective commitment, and group self-esteem as distinct aspects of social identity in the organization. British Journal of Social Psychology, 39(4), 555-77.

Bettencourt, B. A., Brewer, M. B., Croak, M. R., \& Miller, N. (1992). Cooperation and the reduction of intergroup bias: the role of reward structure and social orientation. Journal of Experimental Social Psychology, 28(4), 301-19.

Brewer, M. B., \& Miller, N. (1984). Beyond the contact hypothesis: Theoretical perspectives on desegregation. In N. Miller \& M. B. Brewer (Eds.), Groups in contact: The psychology of desegregation (pp. 281-301). Orlando: Academic.

Brown, T. J., Mowen, J. C., Donavan, D. T., \& Licata, J. W. (2002). The customer orientation of service workers: personality trait effects on self- and supervisor performance ratings. Journal of Marketing Research, 39(1), 110-119.

Bush, V. D., Rose, G. M., Gilbert, F., \& Ingram, T. N. (2001). Managing culturally diverse buyer-seller relationships: the role of intercultural communication competence. Journal of the Academy of Marketing Science, 29(4), 391-404.

Caprariello, P. A., Cuddy, A. J. C., \& Fiske, S. T. (2009). Social structure shapes cultural stereotypes and emotions: a causal test of the stereotype content model. Group Processes and Intergroup Relations, 12(2), 147-155.

Chen, M., \& Bargh, J. A. (1997). Nonconscious behavioral confirmation processes: the self-fulfilling consequences of automatic stereotype activation. Journal of Experimental Social Psychology, 33(5), 541-560.

Conger, J. A., \& Kanungo, R. N. (1998). Charismatic leadership in organizations. Thousand Oaks: Sage.

Conger, J. A., Kanungo, R. N., \& Menon, S. T. (2000). Charismatic leadership and follower effects. Journal of Organizational Behavior, 21(7), 747-67.

Corneille, O., \& Judd, C. M. (1999). Accentuation and sensitization effects in the categorization of multifaceted stimuli. Journal of Personality and Social Psychology, 77(5), 927-941.

Crawford, M. T., Sherman, S. J., \& Hamilton, D. L. (2002). Perceived entitativity, stereotype formation, and the interchangeability of 
group members. Journal of Personality and Social Psychology, 83(5), 1076-94.

Cuddy, A. J. C., Fiske, S. T., \& Glick, P. (2007). The BIAS map: behaviors from intergroup affect and stereotypes. Journal of Personality and Social Psychology, 92(4), 631-648.

Deshpande, R. (1982). The organizational context of market research use. Journal of Marketing, 46(4), 91-101.

Devine, P. G. (1989). Stereotypes and prejudice: their automatic and controlled components. Journal of Personality and Social Psychology, 56(1), 5-18.

Devine, P. G. (1995). Prejudice and outgroup perception. In A. Tesser (Ed.), Advanced social psychology (pp. 467-524). New York: McGraw-Hill.

Dugger, W. M. (1980). Corporate bureaucracy: the incidence of the bureaucratic process. Journal of Economic Issues, 14(2), 399-410.

Eder, P., \& Eisenberger, R. (2008). Perceived organizational support: reducing the negative influence of coworker withdrawal behavior. Journal of Management, 34(1), 55-68.

Eisenberger, R., Huntington, R., Hutchison, S., \& Sowa, D. (1986). Perceived organizational support. Journal of Applied Psychology, 71(3), 500-507.

Ellemers, N., de Gilder, D., \& Haslam, S. A. (2004). Motivating individuals and groups at work: a social identity perspective on leadership and group performance. Academy of Management Review, 29(3), 459-478.

Engle, E. M., \& Lord, R. G. (1997). Implicit theories, self-schemas, and leader-member exchange. Academy of Management Journal, 40(4), 988-1010.

Fiske, S. T. (1998). Stereotyping, prejudice, and discrimination. In S. T. Gilbert, S. F. Fiske, \& L. Gardner (Eds.), Handbook of social psychology (pp. 357-411). Boston: Gardner.

Fornell, C., \& Larcker, D. F. (1981). Evaluating structural equation models with unobservable variables \& measurement error. Journal of Marketing Research, 18(1), 39-50.

Fritz, W. (1996). Market orientation and corporate success: findings from Germany. European Journal of Marketing, 30(8), 59-74.

Gardner, R. C. (1994). Stereotypes as consensual beliefs. In M. P. Zanna \& J. M. Olson (Eds.), The psychology of prejudice: The Ontario symposium (pp. 1-31). New Jersey: Erlbaum.

Gouldner, A. W. (1960). The norm of reciprocity: a preliminary statement. American Sociological Review, 25(2), 161-78.

Grinstein, A. (2008). The relationships between market orientation and alternative strategic orientations: a meta-analysis. European Journal of Marketing, 42(1), 115-34.

Hackman, J. R., \& Oldham, G. R. (1975). Development of the job diagnostic survey. Journal of Applied Psychology, 60(2), 159-170.

Harris, L. C., \& Ogbonna, E. (2001). Strategic human resource management, market orientation, and organizational performance. Journal of Business Research, 51(2), 157-66.

Hartline, M. D., \& Ferrell, O. C. (1996). The management of customer-contact service employees: an empirical investigation. Journal of Marketing, 60(4), 52-70.

Heilman, M. E., \& Okimoto, T. G. (2008). Motherhood: a potential source of bias in employment decisions. Journal of Applied Psychology, 93(1), 189-198.

Herr, P. M., Kardes, F., \& Kim, J. (1991). Effects of word-of-mouth and product-attribute information on persuasion: an accessibilitydiagnosticity perspective. Journal of Consumer Research, 17(4), 454-58.

Heskett, J. L., Sasser, W. E., Jr., \& Schlesinger, L. A. (1997). The service profit chain. New York: Free.

Hilton, J. L., \& von Hippel, W. (1996). Stereotypes. Annual Review of Psychology, 47(1), 237-71.

Hoffman, K. D., \& Ingram, T. N. (1992). Service provider job satisfaction and customer-oriented performance. Journal of Services Marketing, 6(2), 68-78.
Hogg, M., \& Abrams, D. (1988). Social identifications: A social psychology of intergroup relations \& group processes. London: Routledge.

Homburg, C., \& Stock, R. M. (2004). The link between salespeople's job satisfaction and customer orientation in a business-tobusiness context: a dyadic analysis. Journal of the Academy of Marketing Science, 32(2), 144-58.

Homburg, C., Wieseke, J., \& Hoyer, W. (2009). Social identity and the service-profit chain. Journal of Marketing, 73(2), 38-54.

Hopkins, N., Reicher, S., \& Levine, M. (1997). On the parallels between social cognition and the 'New Racism'. British Journal of Social Psychology, 36, 305-29.

Jones, E., Bush, P., \& Dacin, P. (2003). Firm market orientation and salesperson customer orientation: interpersonal and intrapersonal influences on customer service and retention in business-tobusiness buyer-seller relationships. Journal of Business Research, 56(4), 323-41.

Katz, I., \& Hass, R. G. (1988). Racial ambivalence and American value conflict: correlational and priming studies of dual cognitive structures. Journal of Personality and Social Psychology, 55(6), 893-905.

Kearney, E., Gebert, D., \& Voelpel, S. C. (2009). When and how diversity benefits teams: the importance of team members' need for cognition. Academy of Management Journal, 52(3), 581-598.

Kelman, H. C. (1958). Compliance, identification, and internalization: three processes of attitude change. Journal of Conflict Resolution, 2(1), 51-60.

Klein, J. G., Ettenson, R., \& Morris, M. D. (1998). The animosity model of foreign product purchase: an empirical test in the People's Republic of China. Journal of Marketing, 62(1), 89-100.

Kleinbaum, D. G., Kupper, L. L., Muller, K. E., \& Nizam, A. (1998). Applied regression analysis and other multivariate methods. Pacific Grove: Duxbury.

Krueger, J. I., Hall, J., Villano, P., \& Jones, M. (2008). Attribution and categorization effects in the representation of gender stereotypes. Group Processes Intergroup Relations, 11(3), 401-414.

Lee, N., Sandfield, A., \& Dhaliwal, B. (2007). An empirical study of salesperson stereotypes amongst UK students \& their implications for recruitment. Journal of Marketing Management, 23(7), 723-744.

Leonard, B. (2000). Worker productivity may be tangled in corporate bureaucracy. HR Magazine, November 2000, 34.

Lepore, L., \& Brown, R. (1997). Category and stereotype activation: is prejudice inevitable? Journal of Personality \& Social Psychology, 72(2), 275-87.

Liu, S. S., Luo, X., \& Shi, Y. (2002). Integrating customer orientation, corporate entrepreneurship, and learning orientation in organizations-in-transition: an empirical study. International Journal of Research in Marketing, 19(4), 367-82.

Livingston, K. R., Andrews, J. K., \& Harnard, S. (1998). Categorical perception effects induced by category learning. Journal of Experimental Psychology: Learning, Memory, and Cognition, 24(3), 732-753.

Luthans, F., \& Kreitner, R. (1985). Organizational behavior modification and beyond: an operational and social learning approach. Glenview: Scott Foresman.

MacKenzie, S. B., Podsakoff, P. M., \& Ahearne, M. J. (1998a). Some possible antecedents and consequences of in-role and extra-role salesperson performance. Journal of Marketing, 62(3), 87-98.

MacKenzie, S. B., Podsakoff, P. M., \& Rich, G. A. (1998b). Transformational and transactional leadership and salesperson performance. Journal of the Academy of Marketing Science, 29(2), 115-134.

McConahay, J. B., Hardee, B. B., \& Batts, V. (1981). Has racism declined in America? It depends on who is asking \& what is asked. Journal of Conflict Resolution, 25(4), 563-79.

Miller, N., Brewer, M. B., \& Edwards, K. (1985). Cooperative interaction in desegregated settings: a laboratory analogue. Journal of Social Issues, 41(3), 63-81. 
Morhart, F. M., Herzog, W., \& Tomczak, T. (2009). Brand-specific leadership: turning employees into BR\& champions. Journal of Marketing, 73(5), 122-142.

Muthén, L. K., \& Muthén, B. O. (2006). Mplus user's guide (4th ed.). Los Angeles: Muthén \& Muthén, available at: http://www. statmodel.com.

Nunnally, J. C., \& Bernstein, I. H. (1994). Psychometric theory (3rd ed.). New York: McGraw-Hill.

O'Reilly, C. (1989). Corporations, culture and commitment: motivation and social control in organizations. California Management Review, 31(4), 9-25.

Oakes, P. J., Haslam, S. A., \& Turner, J. C. (1994). Stereotyping and social reality. Oxford: Blackwell.

Ouellet, J. (2007). Consumer racism and its effects on domestic crossethnic product purchase: an empirical test in the United States, Canada, and France. Journal of Marketing, 71(1), 113-128.

Park, B., \& Judd, C. M. (1990). Measures and models of perceived group variability. Journal of Personality and Social Psychology, 59(2), 173-82.

Pettigrew, T. F., \& Tropp, L. R. (2006). A meta-analytic test of intergroup contact theory. Journal of Personality and Social Psychology, 90(5), 751-83.

Pfeffer, J., \& Veiga, J. F. (1999). Putting people first for organizational success. Academy of Management Executives, 13(2), 37-48.

Piercy, N. F. (1994). The real strategic issues versus organizational bureaucracy and administrative neatness. Management Decision, $32(4), 5-8$.

Piercy, N. F., Harris, L. C., \& Lane, N. (2002). Market orientation and retail operatives' expectations. Journal of Business Research, 55 (4), 261-73

Piercy, N. F., Cravens, D. W., Lane, N., \& Vorhies, D. W. (2006). Driving organizational citizenship behaviors and salesperson inrole behavior performance: the role of management control and perceived organizational support. Journal of the Academy of Marketing Science, 34(2), 244-62.

Platow, M. J., \& van Knippenberg, D. (2001). A social identity analysis of leadership endorsement: the effects of leader ingroup prototypicality and distributive intergroup fairness. Personality and Social Psychology Bulletin, 27(11), 1508-1519.

Puffer, S. M. (1987). Prosocial behavior, noncompliant behavior, and work performance among commission salespeople. Journal of Applied Psychology, 72(4), 615-21.

Queller, S., Schell, T., \& Winter, M. (2006). A novel view of betweencategories contrast and within-category assimilation. Journal of Personality and Social Psychology, 91(3), 406-422.

Raudenbush, S. W., \& Bryk, A. S. (2002). Hierarchical linear models: Applications and data analysis methods. Thousand Oaks: Sage.

Rhoades, L., \& Eisenberger, R. (2002). Perceived organizational support: a review of the literature. Journal of Applied Psychology, 87(4), 698-714.

Ruekert, R. W. (1992). Developing a market orientation: an organizational strategy perspective. International Journal of Research in Marketing, 9(3), 225-45.

Schneider, B., Ehrhart, M. G., Mayer, D. M., Saltz, J. L., \& Niles-Jolly, K. (2005). Understanding organization-customer links in service settings. Academy of Management Journal, 48(6), 1017-32.

Shamir, B., House, R. J., \& Arthur, M. B. (1993). The motivational effects of charismatic leadership: a self-concept based theory. Organization Science, 4(4), 577-94.

Shimp, T. A., \& Sharma, S. (1987). Consumer ethnocentrism: construction \& validation of the CETSCALE. Journal of Marketing Research, 24(3), 280-289.

Smidts, A., Pruyn, Ad T. H., \& Van Riel, C. B. M. (2001). The impact of employee communication and perceived external prestige on organizational identification. Academy of Management Journal, 44(5), 1051-62.
Smith, C. A., Organ, D., \& Near, J. P. (1983). Organizational citizenship behavior: its nature and antecedents. Journal of Applied Psychology, 68(4), 653-63.

Spencer-Rodgers, J., Hamilton, D. L., \& Sherman, S. J. (2007). The central role of entitativity in stereotypes of social categories and task groups. Journal of Personality and Social Psychology, 92 (3), 369-388.

Stephan, W. G., \& Stephan, C. W. (1984). The role of ignorance in intergroup relations. In N. Miller \& M. B. Brewer (Eds.), Groups in contact: The psychology of desegregation (pp. 229-257). Orlando: Academic

Tajfel, H. (1978). Differentiation between social groups. Studies in the social psychology of intergroup relations. London: Academic.

Tajfel, H., \& Turner, J. C. (1979). An integrative theory of intergroup conflict. In W. G. Austin \& S. Worchel (Eds.), The social psychology of intergroup relations (pp. 33-47). Monterey: Brooks-Cole.

Tajfel, H., \& Turner, J. C. (1986). The social identity theory of inter-group behavior. In S. Worchel \& W. G. Austin (Eds.), Psychology of intergroup relations (pp. 7-24). Chicago: Nelson-Hall.

Terry, D. J., \& Hogg, M. A. (1996). Group norms \& the attitudebehaviour relationship: a role for group identification. Personality and Social Psychology Bulletin, 22(8), 776-93.

Thomas, R. W., Soutar, G. N., \& Ryan, M. M. (2001). The selling orientation-customer orientation (S.O.C.O.) scale: a proposed short form. Journal of Personal Selling and Sales Management, 21(1), 63-69.

Turner, J. C., Hogg, M. A., Oakes, P. J., Reicher, S. D., \& Wetherell, M. S. (1987). Rediscovering the social group-a selfcategorization theory. Worchester: Billing.

Turner, R. N., Voci, A., \& Hewstone, M. (2007). Reducing explicit and implicit outgroup prejudice via direct and extended contact: the mediating role of self-disclosure and intergroup anxiety. Journal of Personality and Social Psychology, 93(3), 369-88.

Tyler, T. R. (1999). Why people cooperate with organizations. Research in Organizational Behavior, 21, 201-46.

Tyler, T. R., \& Blader, S. L. (2005). Can businesses effectively regulate employee conduct? The antecedents of rule following in work settings. Academy of Management Journal, 48(6), 1143-58.

Ullrich, J., Christ, O., \& van Dick, R. (2009). Substitutes for procedural fairness: prototypical leaders are endorsed whether they are fair or not. Journal of Applied Psychology, 94(1), 235-344.

Van de Ven, A. H., \& Ferry, D. (1980). Measuring and assessing organizations. New York: Wiley.

Van Knippenberg, D., \& Hogg, M. A. (2003). A social identity model of leadership effectiveness. In R. M. Kramer \& B. M. Staw (Eds.), Research in organizational behavior (pp. 245-297). Amsterdam: Elsevier.

Vonofakou, C., Hewstone, M., \& Voci, A. (2007). Contact with outgroup friends as a predictor of meta-attitudinal strength and accessibility of attitudes toward gay men. Journal of Personality and Social Psychology, 92(5), 804-20.

Vorauer, J. D., Main, K. J., \& O'Connell, G. B. (1998). How do individuals expect to be viewed by members of lower status groups? Content and implications of meta-stereotypes. Journal of Personality and Social Psychology, 75(4), 917-37.

Wieseke, J., Homburg, C., \& Lee, N. (2008). Understanding the adoption of new brands through salespeople: a multilevel framework. Journal of the Academy of Marketing Science, 36(2), 278-91.

Wittenbrink, B., Judd, C. M., \& Park, B. (1997). Evidence for racial prejudice at the implicit level and its relationship with questionnaire measures. Journal of Personality and Social Psychology, 72 (2), 262-74.

Zyphur, M. J., Warren, C. R., Landis, R. S., \& Thoresen, C. J. (2007). Self-regulation and performance in high-fidelity simulations: an extension of ego-depletion research. Human Performance, 20(2), $103-118$. 